\title{
Complex variant of Philadelphia translocation involving chromosomes 1, 9, 12 and 22 in a case with chronic myeloid leukemia (CML)
}

\section{Kompleksna varijantna translokacija Philadelphia kromosoma koja uključuje kromosome 1, 9, 12 i 22 u slučaju kronične mijeloične leukemije (KML)}

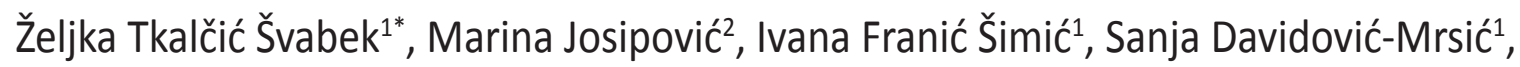 \\ Nadira Duraković ${ }^{3}$
}

\begin{abstract}
Aim: Chronic myeloid leukemia (CML) is characterized by the Philadelphia ( $\mathrm{Ph}$ ) chromosome created by the reciprocal translocation $t(9 ; 22)(q 34 ; q 11)$, resulting in the hybrid gene breakpoint cluster region - Abelson (BCR-ABL1). Around 5-10\% of CML cases develop complex variant $\mathrm{Ph}$ translocations involving one or more chromosomal regions besides 9 and 22. In this study we report a case of acute lymphoblastic leukemia (ALL) developed from CML displaying a novel four-way translocation. Case report: A complete blood analysis of a 46-yearold male patient showed an increase in white blood cells, lower levels of red blood cells and platelets. Bone-marrow sample was subjected to the conventional cytogenetic (Giemsabanding) and fluorescence in situ hybridization methods and the four - way translocation was identified. Considering hepatosplenomegaly and breakpoint cluster region that was characterized as major (M-bcr) on the quantitative real-time polymerase chain reaction (RQPCR), ALL was diagnosed as a transformation from CML. Conclusion: This study reports a new four-way translocation ins(22;1)(q11.2;q31q32)t(1;9;12;22)(q32;q34;q13;q11.2) in an ALL patient developed from the CML and was cross-checked in Mitelman Database of Chromosome Aberrations and Gene Fusions in Cancer.
\end{abstract}

Key words: bone marrow; chronic myelogenous leukemia; cytogenetics; Philadelphia chromosome

Sažetak. Cilj: Kronična mijeloična leukemija (KML) karakterizirana je Philadelphia kromosomom (Ph) koji nastane recipročnom translokacijom $\mathrm{t}(9 ; 22)(\mathrm{q} 34 ; \mathrm{q} 11.2)$ i rezultira fuzijskim genom BCR-ABL1. Kompleksna varijantna translokacija uključuje jos jedan ili više kromosoma uz kromosome 9 i 22 te se javlja u 5 do $10 \%$ svih slučajeva KML-a. U ovoj studiji prijavljujemo novi slučaj varijantne akutne limfoblastične leukemije (ALL) koja se transformirala iz KML-a. Prikaz slučaja: Kompletna krvna slika 46-godišnjeg pacijenta pokazala je povećane vrijednosti bijelih krvnih stanica, a snižene vrijednosti crvenih krvih stanica i trombocita. Uzorak koštane srži (KS) poslan je na klasičnu citogenetičku (Giemsapruganje) i fluorescentu in situ hibridizacijsku (FISH) analizu kojima je potvrđena nova varijantna translokacija između četiriju kromosoma. S obzirom na hepatosplenomegaliju i područje prijelomne točke koja je karakterizirana kao "major” (M-bcr), korištenjem kvantitativne polimerazne lančane reakcije u stvarnom vremenu dijagnosticiran je ALL u transformaciji iz KML-a. Zaključak: Ova studija prijavljuje novu varijantnu translokaciju koja obuhvaća 4 kromosoma ins(22;1)(q11.2;q31q32)t(1;9;12;22)(q32;q34;q13;q11.2) kod pacijenta S ALL-om transformiranim iz KML-a, na temelju provjere u bazama podataka Mitelman Database of Chromosome Aberrations and Gene Fusions in Cancer.

Ključne riječi: citogenetika; koštana srž; kronična mijeloična leukemija; Philadelphia kromosom
${ }^{1}$ University Hospital Centre Zagreb, Clinical Department of Laboratory Diagnostics, Divison for Cytogenetics, Zagreb

${ }^{2}$ General Hospital "Dr. Josip Benčević", Department of Laboratory Diagnostics, Slavonski Brod

${ }^{3}$ University Hospital Centre Zagreb, Division of Hematology, Zagreb

"Corresponding author:

Željka Tkalčić Švabek, mag. med. biochem University Hospital Centre Zagreb, Clinical Department of Laboratory Diagnostics, Divison for Cytogenetics Kišpatićeva 12, 10000 Zagreb e-mail: zeljka.tkalcic@gmail.com

http://hrcak.srce.hr/medicina 


\section{INTRODUCTION}

Chronic myeloid leukemia (CML) is a myeloproliferative disorder characterized by the presence of the Philadelphia (Ph) chromosome resulting from the reciprocal translocation $\mathrm{t}(9 ; 22)(\mathrm{q} 34 ; \mathrm{q} 11)^{1}$. This translocation between the long arms of chromosome 9 and 22 results in a shortened chromosome $22(\mathrm{Ph})$ and found in over $90 \%$ of $\mathrm{CML}$ patients. The final product of this genetic rearrangement is a $210 \mathrm{kDa}$ cytoplasmic fusion protein, p210 $\mathrm{BCR} / \mathrm{ABL}$,

Chronic myeloid leukemia (CML) is a myeloproliferative disorder characterized by the presence of the Philadelphia $(\mathrm{Ph})$ chromosome resulting from the reciprocal translocation $\mathrm{t}(9 ; 22)(\mathrm{q} 34 ; \mathrm{q} 11)$. In $5-10 \%$ of newly diagnosed CML cases, one or more additional chromosomes were involved in the translocation, which are termed variant or complex translocation.

which is essential and sufficient for the malignant transformation of CML, and also responsible for the phenotypic abnormalities of chronic phase $\mathrm{CML}^{2}$. At the molecular level reciprocal exchange involves Abelson oncogene ( $A B L 1)$ located on chromosome 9 and the breakpoint cluster region (BCR) gene on chromosome 22 forming a BCRABL1 hybrid gene ${ }^{3}$. In 5-10\% of newly diagnosed $\mathrm{CML}$ cases, one or more additional chromosomes were involved in the translocation, which are termed variant or complex translocation ${ }^{4}$. The treatment of CML was revolutionized by the introduction of imatinib mesylate (IM), a BCR-ABL1 tyrosine kinase inhibitor $(\mathrm{TKI})^{5}$. It blocks the BCR-ABL1 tyrosine kinase activity and subsequently induces apoptosis followed by the reduction in the prolif-

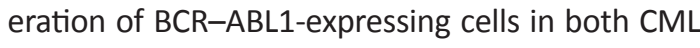
and acute lymphocytic leukemia (ALL). The treatment of CML patients with IM significantly increased the survival and improved the quality of life $^{6}$. The second-generation BCR-ABL1 TKIs, nilotinib and dasatinib, showed significant activity in clinical trials in patients intolerant or resistant to IM therapy 5 . To the best of our knowledge, this case report is the first to study four-way $\mathrm{Ph}$ translocation 46, XY, ins(22;1)(q11.2;q31q32) $\mathrm{t}(1 ; 9 ; 12 ; 22)(\mathrm{q} 32 ; \mathrm{q34} ; \mathrm{q13} ; \mathrm{q11}$.2) in a CML patient with a new complex rearrangement.

\section{CASE REPORT}

A 46-year-old male patient was diagnosed with ALL in 2016. The hematological analysis revealed a white blood cell (WBC) count of $70.8 \times 10^{9} / \mathrm{L}$ (normal range, 3.4-9.7 $\times 10^{9} / \mathrm{L}$ ), eosinophils $2 \%$ (normal range, 0-7\%), basophils 2\% (normal range, 0-1\%), immature neutrophil value $9 \%$ (normal range, 0-2\%), a mature neutrophil value of $40 \%$ (normal range, 44-72\%), a lymphocyte value of $5 \%$ (20-46\%), a metamyelocyte value of $1 \%$ (normal range, $0-0 \%$ ), a myelocyte value of $2 \%$ (normal range, $0-0 \%$ ), a promyelocyte value $1 \%$ (normal range, $0-0 \%$ ), a blast cells $38 \%$ (normal range, $0-0 \%$ ), a red blood cell (RBC) count of $2.87 \times 10^{12} / \mathrm{L}$, (normal range, 4.34-5.72 $\times 10^{12} / \mathrm{L}$ ), a hemoglobin $(\mathrm{Hb})$ level of $85 \mathrm{~g} / \mathrm{L}$ (normal range, 138-175 g/L), a hematocrit (Htc) of $0.261 \mathrm{~L} / \mathrm{L}$ (normal range, 0.415-0.530 L/L), a mean corpuscular volume (MCV) of $91.0 \mathrm{fL}$ (normal range, 83.0-97.2 fL), a mean corpuscular hemoglobin (MCH) level of $29.5 \mathrm{pg}$ (normal range, 27.4-33.9 $\mathrm{pg})$, a mean corpuscular hemoglobin concentration (MCHC) of $325 \mathrm{~g} / \mathrm{L}$ (normal range, 320-345 $\mathrm{g} / \mathrm{L}$ ), a platelet count of $5 \times 10^{9} / \mathrm{L}$ (normal range, $158-424 \times 10^{9} / \mathrm{L}$ ), and an erythrocyte sedimentation rate of $14 \mathrm{~mm} / \mathrm{h}$ (normal range, $2-13 \mathrm{~mm} / \mathrm{h}$ ).

\section{Complete blood count laboratory test}

Complete blood count (CBC) was performed using an Automatic Hematological Analyzer (Sysmex xe 5000, America). The hematological analyzer that was used for the complete blood count measured the level of WBCs, RBCs, platelets and $\mathrm{Hb}$, the MCV, $\mathrm{MCH}, \mathrm{MCHC}$. The patient's peripheral blood (PB) sample was taken in a test tube with tripotassium ethylenediaminetetraacetic acid ( $\left.K_{3}-E D T A\right)$ anticoagulant. An increase in WBCs, lower levels of RBCs and platelets, and the appearance of blast cells showed suspicion of hematological disorder, and the patient was considered for further examination.

\section{RQ-PCR}

Reverse transcription real time quantitative polymerase chain reaction (RQ-PCR) is routinely used to quantify levels of BCR-ABL1 mRNA transcripts in $P B$ and bone marrow (BM) samples $^{7}$. The fusion protein encoded by BCR-ABL1 
varies in size, depending on the breakpoint in the BCR gene. Three breakpoint cluster regions have been characterized to date: major (M-bcr), minor (m-bcr) and micro (mu-bcr). The vast majority of CML patients have a p210 BCR-ABL1 gene (Mbcr), and the smallest of the fusion proteins, p190 BCR-ABL1, (m-bcr breakpoint) is principally associated with $\mathrm{Ph}$-positive $\mathrm{ALL}$. CML resulting from a p230 BCR-ABL1 gene (mu-bcr breakpoint) is also rare, and has been associated with the chronic neutrophilic leukemia variant and/or with marked thrombocytosis ${ }^{8}$ In this case, the M-bcr transcript from the BM sample was confirmed.

\section{Cytogenetic analysis}

BM specimen for RQ-PCR, conventional cytogenetic analysis, and fluorescence in situ hibridisa- tion (FISH) analysis was collected before treatment. Conventional cytogenetic analysis was performed on unstimulated 24-hour culture of a BM specimen using a standard technique ${ }^{9}$. In total, 15 Giemsa banding (G-banding) BM metaphases were analyzed. Fifteen metaphases were captured and analyzed on fluorescence light microscope (Carl Zeiss Microlmaging GmbH, Gottingen, Germany) and Ikaros software (Metasystem, Heidelberg Germany), and all had the present variant translocation. The karyotype was described according to the International System for Human Cytogenetic Nomenclature (ISCN, 2016) ${ }^{10}$. The conventional cytogenetic analysis identified the presence of a complex, four-way Ph chromosome translocation ins(22;1)(q11.2;q31q32) $\mathrm{t}(1 ; 9 ; 12 ; 22)(\mathrm{q} 32 ; \mathrm{q34} ; \mathrm{q13} ; \mathrm{q11})$ (Figure 1).

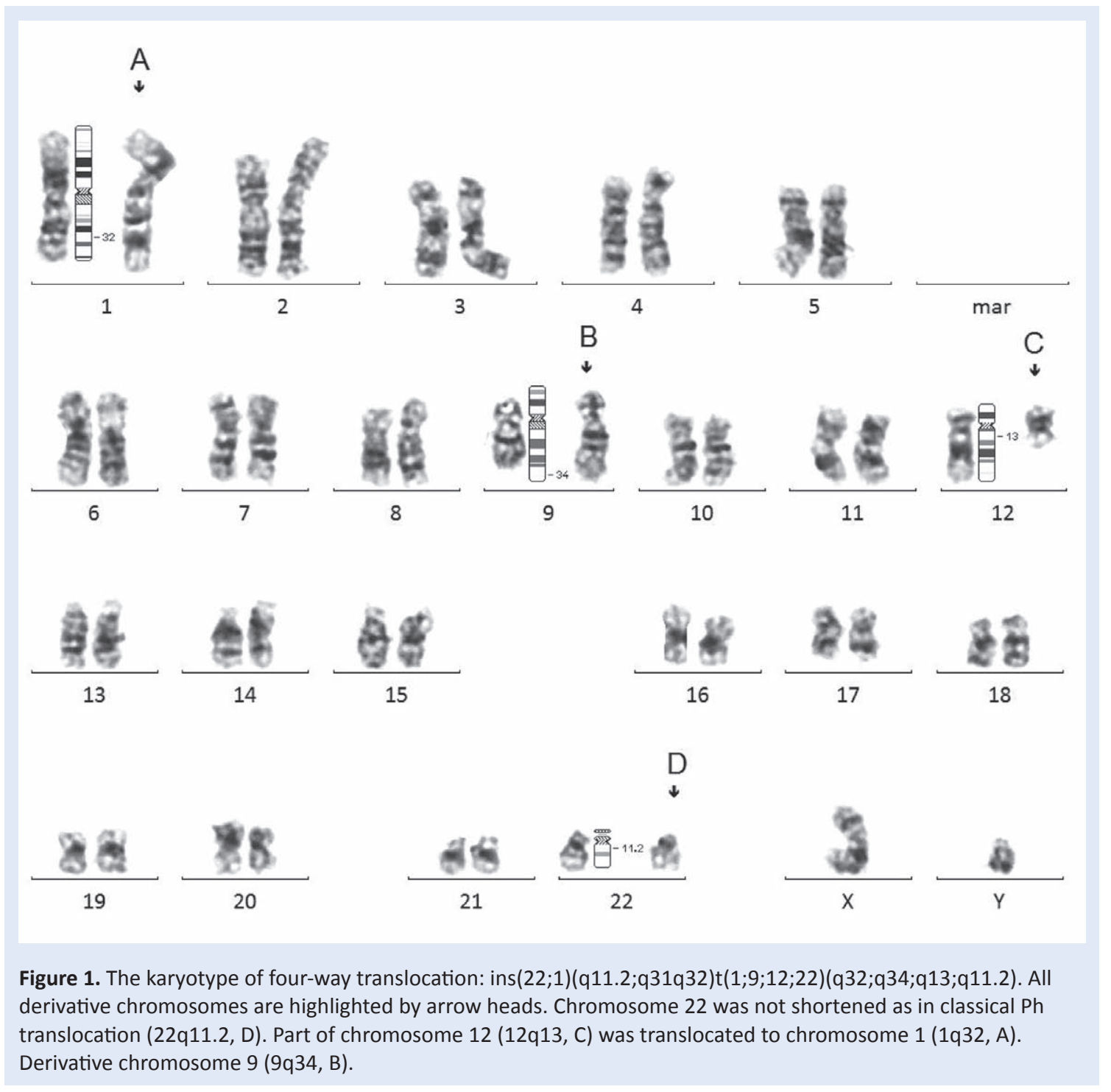




\section{Fluorescence in situ hibridisation (FISH) analysis}

FISH procedure was performed on fixed cell suspension obtained with conventional cytogenetic method on microscope slides according to the manufacturer's instructions. The process of denaturation and hybridization was performed on the automated machine Hybrate (HYBrite ${ }^{T M}$, Vysis $\mathrm{GmbH}$, Stuttgard-Fasanenhof, Germany). As a probe was used Vysis LSI BCR-ABL1 Dual color Dual fusion Translocation Probe kit (Abbott Labo-

This case report is the first to study four-way Ph translocation 46, XY, ins(22;1)(q11.2;q31q32)t(1;9;12;22) (q32; $\mathbf{3 4} ; q 13 ; q 11.2$ ) in a CML patient with a new complex rearrangement.

ratories, Illinois, U.S.A.). Two hundred interphase cells of patient were analyzed on fluorescence microscope (Carl Zeiss Microlmaging $\mathrm{GmbH}$, Gottingen, Germany) under 1000× magnification. Associated optical filters were green, orange, and triplet - a filter that can see aqua, red, and green signals at the same time. Image capturing and processing were performed using an Isis imaging system (Isis software, Altlussheim, Germany). The result was expressed as a percentage of $\mathrm{Ph}$ positive interphase cells.

A probe used for FISH is a mixture of the LSI BCR probe labeled with SprectrumGreen and the LSI ABL1 probe labeled with SprectrumOrange. The $B C R$ probe is labeled with SpectrumGreen that spans a genomic distance of about 1.5 megabases (Mb). The ABL1 probe labeled with SpectrumOrange includes $650 \mathrm{~kb}$, and it extends from an area centromeric of the argininosuccinate synthetase gene (ASS) to telomeric of the last ABL1 exon ${ }^{11}$.

To confirm translocation, Whole Chromosome Probes (WCP) (KREATECH Diagnostics, Amsterdam, The Netherlands) was also used. WCP are optimized to detect unique sequences spanning the length of individual entire chromosomes. The analysis carried out with these probes was performed on cultured cells on metaphase chromosomes ${ }^{12}$.

In general, FISH analysis of interphase nuclei of the ABL1 (9q34) gene was identified by fluores- cent red signal, and BCR (22q11.2) gene by green signal. Negative cells without translocation include two red and two green signals (2R2G). With the dual color, dual fusion BCR-ABL1 probe, the positive reciprocal $t(9 ; 22)$ signal pattern revealed two fusions (derivative chromosome 9 and derivative chromosome 22), one red (normal chromosome 9) and one green (normal chromosome 22) (2F1R1G). Cases with variant translocation $t(9 ; 22)$ appears with one fusion signal (derivative chromosome 22), two red (normal and derivative chromosome 9) and two green signals (normal chromosome 22 and third involved chromosome) (1F2R2G). For present study, BCR-ABL1 translocation was detected by FISH analysis in $91 \%$ of the 200 interphase nuclei counted, and with 1F2R2G signals. (Figure 2). The remaining $9 \%$ of the cells were $\mathrm{Ph}$ negative with 2R2G signals.

\section{Treatment}

The patient was treated initially with standard induction therapy for ALL which include HyperCVAD-HD-MA and IM at daily dose of $600 \mathrm{mg}$. On IM the patient developed an allergy in the form of a generalized rash and urticaria. For this reason, the patient was considered intolerant to IM, and a second-generation TKI, nilotinib, $200 \mathrm{mg}$ $2 \times 2$ was started orally. After remission was achieved, the treatment was continued with transplantation of allogenic HLA related PB stem cells. Three months after the transplant, there is a relapse of the disease and the return of the primary clone of the disease. It is necessary to reintroduce the nilotinib that the patient took before transplantation to keep the disease under control until the onset of lymphocyte action. The dose was $600 \mathrm{mg}$ daily. One month after, patient received first of total two donor lymphocyte infusion from original donor. Since then, the disease is in remission, and the patient has no sign of graft versus host disease (GVHD).

\section{DISCUSSION}

There are three distinct clinical stages of $\mathrm{CML}$ : chronic phase (CP), accelerated phase (AP) and blast phase (BP). The $\mathrm{CP}$ lasts several years and is characterized by accumulation of myeloid precur- 

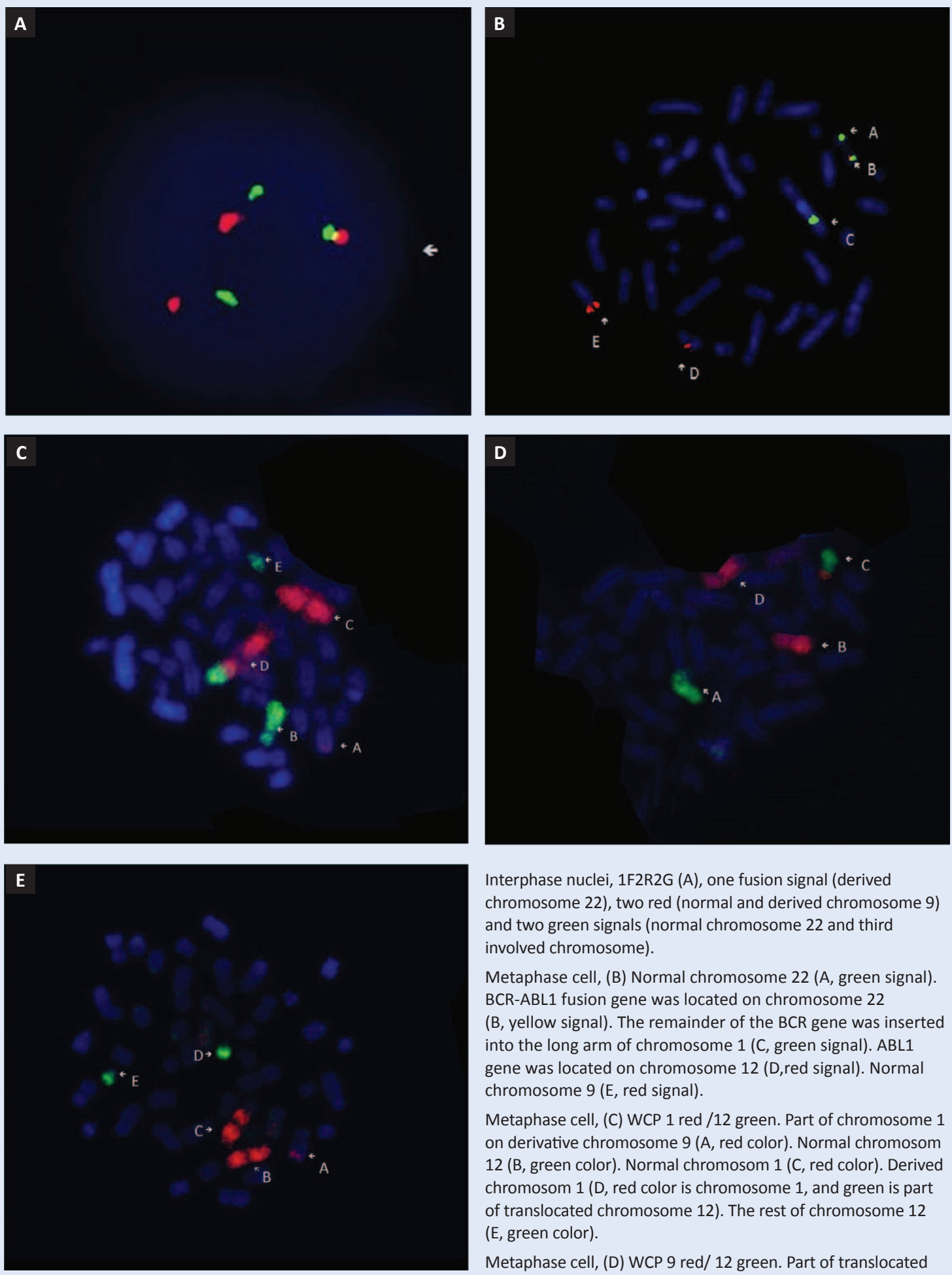

Interphase nuclei, 1F2R2G (A), one fusion signal (derived chromosome 22), two red (normal and derived chromosome 9) and two green signals (normal chromosome 22 and third involved chromosome).

Metaphase cell, (B) Normal chromosome 22 (A, green signal). $B C R-A B L 1$ fusion gene was located on chromosome 22

( $B$, yellow signal). The remainder of the BCR gene was inserted into the long arm of chromosome 1 (C, green signal). ABL1 gene was located on chromosome 12 (D,red signal). Normal chromosome 9 (E, red signal).

Metaphase cell, (C) WCP 1 red /12 green. Part of chromosome 1 on derivative chromosome 9 (A, red color). Normal chromosom 12 (B, green color). Normal chromosom 1 (C, red color). Derived chromosom 1 (D, red color is chromosome 1 , and green is part of translocated chromosome 12). The rest of chromosome 12 ( $E$, green color).

Metaphase cell, (D) WCP 9 red/ 12 green. Part of translocated chromosome 12 on derivative chromosome 1 ( $A$, green color). Normal chromosome 9 (B, red color). The rest of chromosome 12 ( $C$, green color) with part of the ABL1 gene from the

Figure 2. Representative FISH signal patterns using
LSI BCR-ABL1 Dual color Dual fusion Translocation Probe Kit and Whole Chromosome Probes (WCP) derivative chromosome 9 (C, red color). Derivative chromosome 9 (D, red color)

Metaphase cell, (E) WCP 1 red/ 22 green. Part of chromosome 1 on derivative chromosome 9 (A, red color). Normal chromosom 1 (B, red color). Derivative chromosome 1 (C, red color). Normal chromosom 22 (D, green color). Derivative Ph chromosom 22 ( $\mathrm{E}$, green color). 
sors and mature cells in BM, PB and extramedullary sites. The AP lasts 4 to 6 months and is characterized by an increase in disease burden and in the frequency of progenitor/precursor cells rather than terminally differentiated cells. The BP lasts only a few months and is characterized by the rapid expansion of a population of myeloid or lymphoid differentiation-arrested blast cells ${ }^{13}$. In present case, the patient was administrated in BP of ALL, but considered hepatosplenomegaly and breakpoint cluster region that was characterized as major (M-bcr) on RQ$P C R$, it was diagnosed as a transformation from CML. CML is primarily caused due to balanced translocation between the long arms of 9 and 22 chromosomes and secondarily by the variant and complex translocation patients. In such cases, the third, fourth, or even fifth chromosome was involved and is termed as four-, five-, or sixway translocation ${ }^{6}$. The mechanisms of the generation of the variant translocations are not fully understood, but some authors have suggested 2 different mechanisms: a 1-step mechanism in which chromosome breakage occurs simultaneously on 3 or 4 different chromosomes in 3-way or 4-way translocation, respectively, and a 2-step mechanism involving 2 sequential translocations in which a standard $t(9 ; 22)$ translocation is followed by a second translocation involving additional chromosomes ${ }^{1}$.

Genomic instability is probably responsible for two major problems in CML: TKI resistance and disease progression ${ }^{14}$. The majority of CML-BP patients not previously treated with TKIs do initially respond to treatment with these agents, either alone or in combination with conventional chemotherapeutic drugs, but most still relapse within a few months of achieving a seemingly complete hematologic or even cytogenetic response. Therefore, any CML-BP patient who does respond to modern therapy should proceed, if possible, to allogeneic stem cell transplant prior to relapse.To date, there is strong evidence supporting the idea that the level of BCR-ABL1 kinase activity plays a pivotal role in almost all $\mathrm{CML}$ patients undergoing progression and that BCRABL1-induced genetic/chromosomal abnormalities can predispose to transformation and/or markedly influence the aggressiveness of the blast crisis progenitor cell clone ${ }^{15}$.

Since the conventional cytogenetic analysis and the FISH method can not determine which exact genes other than BCR-ABL1 are involved, we can not predict the effect of other translocation or $B C R$ insertion on patient prognosis or response to therapy. Also, in the literature, we did not find a description of the aforementioned translocation and insertion in leukemia. Numerous studies have deal with the topic of variant translocation in $\mathrm{CML}$ and response to TKI, but the correlation between poorer TKI response in variant translocation patients has not been demonstrated ${ }^{1,16}$. Up to now, patient showed a good response to nilotinib treatment and transplantation of allogenic HLA. At the time this article was written, 315 days has elapsed since transplantation, and the disease is in remission.

\section{CONCLUSION}

In conclusion, this study reports new four-way translocation 46, $\mathrm{XY}$, ins(22;1)(q11.2;q31q32) $\mathrm{t}(1 ; 9 ; 12 ; 22)(\mathrm{q} 32 ; \mathrm{q} 34 ; \mathrm{q} 13 ; \mathrm{q} 11.2)$ in an ALL patient developed from the $C M L$ for the first time and was cross-checked in Mitelman Database of Chromosome Aberrations and Gene Fusions in Cancer.

Conflicts of interest statement: the authors report no conflicts of interest.

\section{REFERENCES}

1. Marzocchi G, Castagnetii F, Luatti S, Baldazzi C, Stacchini M, Gugliotta G et al. Variant Philadelphia translocations: molecular-cytogenetic characterization and prognostic influence on frontline imatinib therapy, a GIMEMA Working Party on CML analysis. Blood 2011;117:6793-7000.

2. Salesse S, Verfaillie CM. BCR/ABL: from molecular mechanisms of leukemia induction to treatment of chronic myelogenous leukemia. Oncogene 2002;21:8547-59.

3. Gadhia PK, Shastri GD, Shastri EG. Imatinib Resistance and Relapse in CML Patients with Complex Chromosomal Variants. American Journals of Cancer Science 2015;4:43-53.

4. Gorusu M, Benn P, Li Z, Fang M. On the genesis and prognosis of variant translocations in chronic myeloid leukemia. Cancer Genetics 2007;173:2:97-106.

5. An $X$, Tiwari AK, Sun $Y$, Ding PR, Ashby CR Jr, Chen ZS. $B C R-A B L$ tyrosine kinase inhibitors in the treatment of Philadelphia chromosome positive chronic myeloid leukemia: A review. Leukemia research 2010;34:10: 1255-68. 
6. Asif M, Jamal MS, Khan AR, Naseer MI, Hussain A, Choudhry H. A Novel Four-Way Complex Variant Translocation Involving Chromosome 46,XY,t(4;9;19;22) (q25:q34;p13.3;q11.2) in a Chronic Myeloid Leukemia Patient. Front Oncol 2016;30;6:124.

7. National genetics reference laboratory [Internet]. Salisbury (Wessex): National genetics reference laboratory, Inc. 2006. [cited 2017 Jul 18]. Available from: http:// www.ngrl.org.uk/wessex/bcr_abl_controls.htm.

8. Melo JV. BCR-ABL gene variants. Baillieres Clin Haematol 1997;10:203-22. 9. Rooney DE [Internet]. Human cytogenetics malignancy and acquired abnormalities. 3th Edition. [cited 2017 Apr 11]. Available from: https:// books.google.hr.

10. McGowan-Jordan J, Simons A, Schmidt M. ISCN 2016: An International System for Human Cytogenetic Nomenclature. Basel, Switzerland: Karger Medical and Scientific Publishers, 2016.

11. Abbott Laboratories [Internet]. Abbott molecular oncology and gentics, Product catalog 2015-2016. [cited
2017 Jul 18]. Available from: https://www.molecular. abbott/.

12. Kreatech diagnostics [Internet]. Kreatech diagnostics catalogue 2011-2012. [cited 2017 Jul 18]. Available from: https://www.funakoshi.co.jp/.

13. Radich JP. The Biology of CML blast crisis. Hematology Am Soc Hematol Educ Program 2007;2007:384-91.

14. Skorski T. BCR/ABL, DNA damage and DNA repair: implications for new treatment concepts. Leuk Lymphoma 2008;49:610-4.

15. Perrotti D, Jamieson C, Goldman J, Skorski T. Chronic myeloid leukemia: mechanisms of blastic transformation. J Clin Invest 2010;120:2254-64.

16. Kanakasetty GB, Kuntejowdahalli L, Thanky AH, Dasappa L, Jacob LA, Mallekavu SB et al. Predictive and Prognostic Implications of Variant Philadelphia Translocations in CML: Experience From a Tertiary Oncology Center in Southern India. Clin Lymphoma Myeloma Leuk 2017;17: 52-9. 